\title{
The Contributions of the Gallo Team and the Montagnier Team to the Discovery of the AIDS Virus
}

\author{
Rainer W. Kühne \\ Tuckermannstr. 35, 38118 Braunschweig, Germany \\ e-mail: kuehne70@gmx.de
}

June 13, 2019

\begin{abstract}
In this paper I review the main works of the teams headed by Robert Gallo and Luc Montagnier which led to the discovery of the HIV retrovirus and to the blood test with which one can prove HIV infection. I show that this discovery which saved millions of human lifes (and perhaps the survival of mankind) was made possible only (i) because Gallo's team discovered the Tcell lymphocyte growth factor with which they were able to discover the first retrovirus that infects humans (HTLV-I) and their hypothesis that AIDS is caused by a retrovirus, and (ii) because Montagnier's team detected an antibody against alpha interferon in order to enhance retrovirus production with which they were able to discover the HIV retrovirus and their examination and blood test that gave evidence that HIV causes AIDS. Their examination was improved by the Gallo team who proved without doubt that HIV is the cause of AIDS. I leave the question open whether Gallo deserved the Nobel Prize or whether the Nobel committee's decision to award the prize only to Montagnier and Barre-Sinoussi was correct.
\end{abstract}

\section{Keywords}

AIDS, HIV, HTLV, retrovirus, blood test, Nobel Prize

On December 10, 1981 Gottlieb et al. [1] published a report which stated that four previously healthy homosexual men suffered from multiple viral infections and regarded this as evidence of a new acquired cellular immunodeficiency syndrome. This is now called acquired immunodeficiency syndrome (AIDS). Gottlieb et al. [1] suggested that AIDS is caused by the cytomegalovirus which causes herpes, has an immunodepressing activity, and is transmitted by sexual intercourse.

By contrast, Gallo assumed that AIDS is not caused by the cytomegalovirus, but by a retro- virus similar to HTLV-I. A retrovirus is a singlestranded RNA virus whose RNA is translated by the enzym reverse transcriptase (which was discovered by Temin and Baltimore [2]) into the DNA of the infected cell.

In 1976 Gallo was one of the discoverers of the T-cell growth factor (TCGF) which is now called interleukin-2. It enhances the growth of T-cell lymphocytes [3]. By using TCGF and electron microscopy Gallo's team in 1980 was able to detect the human T-cell leukemia/lymphoma virus (HTLV-I), the first retrovirus that infects humans [4]. Later, in 1982, Gallo's team detected a second human pathogenic retrovirus called HTLV-II which is similar to HTLV-I, but whose proteins differ from those of HTLV-I [5].

The following argumentation suggests that AIDS is caused by a retrovirus.

(i) Some AIDS patients with haemophilia have received purified blood from pools of blood donors which had been filtrated by bacteriological filters. This means that the size of the AIDS pathogen must be smaller than that of bacteria. Viruses and prions satisfy this condition.

(ii) AIDS has a large incubation time, because the first signs of an illness have often appeared months or years after the cause of the infection (sexual intercourse or blood transfusion). This large incubation time is known from prions and also from slow viruses such as retroviruses.

(iii) Both the AIDS pathogen and HTLV-I can be transmitted by sexual intercourse (one main group of AIDS patients are homosexuals) and by blood (another main group of AIDS patients are haemophiliacs who got blood transfusion; other AIDS patients are children whose mothers have AIDS, so the infection has occurred during birth). This condition is not satisfied by prions. Prions are infectious proteins which have been discovered by Prusiner in 1982 as causing scrapie [6]. Later, prions were also shown to cause Creutzfeldt-Jacob disease. Prions are transmitted by eating, never by sexual intercourse (see Prusiner's Nobel lecture for a review 
[7]).

(iv) HTLV-I causes adult T-cell leukemia, that is cancer of lymphocytes which are those white blood cells that are responsible for immune reactions. AIDS means immunodeficiency. The feline leukemia virus (FeLV), a retrovirus that infects cats, can cause either cancer or immune suppression. This suggests that the AIDS pathogen is a retrovirus.

On May 20, 1983 Gallo's team reported to have detected HTLV-I in the lymphocytes from one AIDS patient that were cultured with TCGF. They also detected antigens of HTLV-I [8].

Montagnier learned of Gallo's hypothesis that HTLV-related retroviruses cause AIDS. In 1979 Montagnier's team had detected an antibody against alpha interferon in order to enhance retrovirus production [9]. By using TCGF, anti-interferon, and electron microscopy Montagnier's team reported also on May 20, 1983 the discovery of the lymphadenopathy associated virus (LAV), a retrovirus similar to but different from HTLV, in a homosexual male patient with cervical lymphadenopathy, a symptom that often precedes AIDS. They noted also that the antigen p25 (p25 stands for protein with a molecular weight of 25,000 daltons, where one dalton is equal to one atomic mass unit) of LAV is similar to but different from the antigen p24 of HTLV-I [10].

Gallo was one of the referees of this paper. This paper does not state that LAV is the cause of AIDS.

At a meeting on HTLV in Cold Spring Harbor in September 1983 Montagnier presented data which argued that LAV causes AIDS. This inspired Gallo to search for AIDS viruses which differ from HTLV-I and HTLV-II. On May 4, 1984 Gallo's team presented a set of four papers.

(i) Gallo's team reported to have detected HTLV-III in patients with pre-AIDS and AIDS [11]. They have not discussed whether or not HTLV-III differs from LAV.

(ii) Gallo's team detected HTLV-III in 0 of 115 healthy heterosexual subjects, in 1 of 22 healthy homosexual subjects, in 18 of 21 patients with pre-AIDS, and in 26 of 72 patients with AIDS. They noted that a high proportion of AIDS patients contained antibodies of HTLV-III and concluded that HTLV-III causes AIDS [12].

(iii) Gallo's team detected the antigens p24, p55, and p65 of HTLV-III in the serum of patients with AIDS or pre-AIDS [13].

(iv) Gallo's team presented the result of the blood test (a test whether the serum sample includes antibodies reactive against antigens of HTLV-III). Less than 1\% (1 of 186) of healthy heterosexual subjects, $79 \%$ of homosexual men with signs and symptoms that frequently precede AIDS, and $88 \%$ (43 of 49) of patients with AIDS were shown to have antibodies of HTLVIII [14].

On July 20, 1984 Montagnier's team presented a paper which included in detail the results presented at the September 1983 meeting. The blood test reported by Montagnier's team has shown that the antibody to the antigen p25 of LAV was found in the serum of 0 of 189 healthy blood donors, 0 of 70 healthy workers at the Centers of Disease Control, 81 of 113 patients with lymphadenopathy syndrome, 51 of 125 AIDS patients, 1 of 100 homosexual men from San Francisco whose serum had been obtained in 1978 (i.e. before the AIDS epidemia started in the United States), and 12 of 50 homosexual men from San Francisco whose serum had been obtained in 1984. Montagnier's team concluded that LAV causes AIDS [15].

On October 26, 1984 Montagnier's team presented the result of an improved blood test. 35 of 37 AIDS patients were seropositive by a radioimmunoprecipitation assay and 32 of 36 AIDS patients were seropositive by an enzyme-linked immunosorbent solid assay [16].

Meanwhile on August 24, 1984 Levy's team reported to have detected antibodies to AIDSassociated retrovirus (ARV) in all of the investigated 86 AIDS patients [17].

Now there appeared to exist three retroviruses as the cause for AIDS: Montagnier's LAV, Gallo's HTLV-III, and Levy's ARV.

In January 1985 Wain-Hobson et al. presented the nucleotide sequence of LAV [18]. The same month Gallo's team presented the nucleotide sequence of HTLV-III and concluded that LAV, HTLV-III, and ARV are variants of the same virus [19].

On March 22, 1985 the editor of Science wrote that LAV and HTLV-III differ in only $1.5 \%$ of their nucleotides and that ARV differs in $6 \%$ of its nucleotides from those of LAV and HTLVIII. He concluded that the three viruses are not identical, but variants of the same virus [20].

At present LAV, HTLV-III, and ARV are called human immunodeficiency virus HIV-1. Its variants include 0 and $\mathrm{A}$ through $\mathrm{H}$.

Montagnier [21] and his collaborator BarreSinoussi [22] were awarded the Nobel Prize in Physiology or Medicine 2008 for their discovery of human immunodeficiency virus.

\section{References}

[1] M. S. Gottlieb, R. Schroff, H. M. Schanker, J. D. Weisman, P. T. Fan, R. A. Wolf, 
and A. Saxon, Pneumocystis carinii pneumonia and mucosal candidiasis in previously healthy homosexual men - evidence of a new acquired cellular immunodeficiency, The New England Journal of Medicine $\mathbf{3 0 5}$ (1981) 1425-1431.

[2] H. M. Temin and D. Baltimore, RNAdirected DNA synthesis and RNA tumor viruses, Advances in Virus Research $\mathbf{1 7}$ (1972) 129-186.

[3] D. A. Morgan, F. W. Ruscetti, and R. C. Gallo, Selective in vitro growth of $\mathrm{T}$ lymphocytes from normal human bone marrows, Science 193 (1976) 1007-1008.

[4] B. J. Poiesz, F. W. Ruscetti, A. F. Gazdar, P. A. Bunn, J. D. Minna, and R. C. Gallo, Detection and isolation of type $\mathrm{C}$ retrovirus particles from fresh and cultured lymphocytes of a patient with cutaneous Tcell lymphoma, Proceedings of the National Academy of Sciences of the United States of America 77 (1980) 7415-7419.

[5] V. S. Kalyanaraman, M. G. Sarngadharan, M. Robert-Guroff, I. Miyoshi, D. Golde, and R. C. Gallo, A new subtype of human T-cell leukemia virus (HTLV-II) associated with a T-cell variant of hairy cell leukemia, Science 218 (1982) 571-573.

[6] S. B. Prusiner, Novel proteinaceous infectious particles cause scrapie, Science $\mathbf{2 1 6}$ (1982) 136-144.

[7] S. B. Prusiner, Nobel lecture: Prions, Proceedings of the National Academy of Sciences of the United States of America 95 (1998) 13363-13383.

[8] R. C. Gallo, P. S. Sarin, E. P. Gelmann, M. Robert-Guroff, E. Richardson, V. S. Kalyanaraman, D. Mann, G. D. Sidhu, R. E. Stahl, S. Zolla-Pazner, J. Leibowitch, and M. Popovic, Isolation of human T-cell leukemia virus in acquired immune deficiency syndrome (AIDS), Science $\mathbf{2 2 0}$ (1983) 865-867.

[9] F. Barre-Sinoussi, L. Montagnier, R. Lidereau, J. Sisman, J. Wood, and J. C. Chermann, Enhancement of retrovirus production by anti-interferon serum, Annales de Microbiologie 130B (1979) 349-362.

[10] F. Barre-Sinoussi, J. C. Chermann, F. Rey, M. T. Nugeyre, S. Chamaret, J. Gruest, C. Dauguet, C. Axler-Blin, F. VezinetBrun, C. Rouzioux, W. Rozenbaum, and L. Montagnier, Isolation of a T-lymphotropic retrovirus from a patient at risk for acquired immune deficiency syndrome (AIDS), Science 220 (1983) 868-871.

[11] M. Popovic, M. G. Sarngadharan, E. Read, and R. C. Gallo, Detection, isolation, and continuous production of cytopathic retrovirus (HTLV-III) from patients with AIDS and pre-AIDS, Science 224 (1984) 497-500.

[12] R. C. Gallo, S. Z. Salahuddin, M. Popovic, G. M. Shearer, M. Kaplan, B. F. Haynes, T. J. Palker, R. Redfield, J. Oleske, B. Safai, G. White, P. Foster, and P. D. Markham, Frequent detection and isolation of cytopathic retroviruses (HTLV-III) from patients with AIDS and at risk for AIDS, Science 224 (1984) 500-503.

[13] J. Schüpbach, M. Popovic, R. V. Gilden, M. A. Gonda, M. G. Sarngadharan, and R. C. Gallo, Serological analysis of a subgroup of human T-lymphotropic retroviruses (HTLV-III) associated with AIDS, Science 224 (1984) 503-505.

[14] M. G. Sarngadharan, M. Popovic, L. Bruch, J. Schüpbach, and R. C. Gallo, Antibodies reactive with human T-lymphotropic retroviruses (HTLV-III) in the serum of patients with AIDS, Science 224 (1984) 506-508.

[15] V. S. Kalyanaraman, C. D. Cabradilla, J. P. Getchell, R. Narayanan, E. H. Braff, J. C. Chermann, F. Barre-Sinoussi, L. Montagnier, T. J. Spira, J. Kaplan, D. Fishbein, H. W. Jaffe, J. W. Curran, and D. P. Francis, Antibodies to the core protein of lymphadenopathy associated virus (LAV) in patients with AIDS, Science 225 (1984) 321-323.

[16] F. Brun-Vezinet, C. Rouzioux, L. Montagnier, S. Chamaret, J. Gruest, F. BarreSinoussi, D. Geroldi, J. C. Chermann, J. McCormick, S. Mitchell, P. Piot, H. Taelman, K. B. Mirlangu, O. Wobin, N. Mbendi, P. Mazebo, K. Kalambayi, C. Bridts, J. Desmyter, F. M. Feinsod, and T. C. Quinn, Prevalence of antibodies to lymphadenopathy associated retrovirus in African patients with AIDS, Science $\mathbf{2 2 6}$ (1984) 453-456.

[17] J. A. Levy, A. D. Hoffman, S. M. Kramer, J. A. Landis, J. M. Shimabukuro, and L. S. Oshiro, Isolation of lymphocytopathic retroviruses from San Francisco patients with AIDS, Science 225 (1984) 840-842.

[18] S. Wain-Hobson, P. Sonigo, O. Danos, S. Cole, and M. Alizon, Nucleotide sequence 
of the AIDS virus, LAV, Cell 40 (1985) 917.

[19] L. Ratner, R. C. Gallo, and F. Wong-Staal, HTLV-III, LAV, ARV are variants of same AIDS virus, Nature 313 (1985) 636-637.

[20] J. L. Marx, A virus by any other name would still cause AIDS; the assorted AIDS virus isolates are variants of the same virus, but agreement on a name is hard to come by, Science 227 (1985) 1449-1451.

[21] L. Montagnier, Nobel lecture: 25 years after HIV discovery: Prospects for cure and vaccine, Virology 397 (2010) 248-254.

[22] F. Barre-Sinoussi, Nobel lecture: HIV: A discovery opening the road to novel scientific knowledge and global health improvement, Virology 397 (2010) 255-259. 